\title{
TESTIMONY OF THE CONSTRUCTION MASTER WHO HAVE NO COMPETENCE IN THE CASE OF CORRUPTION
}

\author{
Sera Rosanto \\ Advocate Semarang \\ serarosanto09@gmail.com
}

\begin{abstract}
Calculation of state losses can only be done by a master. Master here are not only master in the field of financial audit but also engineers who will calculate the feasibility of construction of a building in case of corruption was related to the construction field. Master who has the competence docalculating the quantity of a building and the price of a building is a person who has a construction management certification. Description of the Construction Master who have no competence in the matter of corruption, the statement becomes invalid.
\end{abstract}

Keywords: Competence, Corruption, Master Testimony.

\section{A. INTRODUCTION}

Criminal law aimed at getting the material truth in revealing a criminal event. Efforts can be made to explore the material truth is through properly accounting in court. Efford is done through the evidence to obtain a conviction on whether or not the criminal act charged, and can determine whether there is an error on the defendant himself. Environmental conditions with changes the fast causes norms and social sanctions are getting loose as well as various subcultures and cultures conflicting foreigners, all of these factors giving effect that gives rise to behavior criminal behavior. ${ }^{1}$

1 Andri Winjaya Laksana, "AKIBAT MINUMAN KERAS DI KOTA SEMARANG ( Studi Kasus Di
Stated by Bambang Peornomo that a proof under the law is basically a process to determine the substance or essence of the facts obtained through a decent size with a mind that is logical to the facts in the past that did not light into facts bright in conjunction with the criminal case. ${ }^{2}$

According to Luhut MP Pangaribuan, Crime Council in the Criminal Code is divided into three phases, namely the pre-adjudication, adjudication and post-adjudication. Pre-adjudication phase is the phase of inquiry and / or investigation,

Polwiltabes Semarang )," Jurnal Pembaharuan HukumJurnal Pembaharuan Hukum I, no. 3 (2014): 297-306.

2 Bambang Purnomo, 2005, The Criminal Procedure Law Principles of Indonesian Criminal Justice, Liberty, Yogyakarta, p. 38 
adjudication phase is the phase of a judge in court examination, and postadjudication phase is a penal punishment.3 luhur MP Pangarian divide the overall activity of criminal proceedings on three (3) phases / stages, namely pre-adjudication phase, the phase of adjudication, and postadjudication phase. A more general division of the criminal proceedings consists of four (4) phases / stages, namely:

1. Stage of investigation

2. Stage of prosecution

3. Stage of examination before the court, and

4. Stage of enforcement of the award.

Criminal procedure law has set all kinds of legal evidence and can be used in the trial of criminal cases. Stated in Article 184 Criminal Code: as follows:

(1) Legal evidence is:
a. witness testimony
b. master testimony
c. letter
d. guidance
e. testimony of the defendant

3 Luhut MP Pangaribuan, 2013, the Criminal Procedure Law, Official Letter Advocate in Court, Papas Sinar Sinanti, Jakarta, p. 35, 36
(2) It is generally already in the know do not need to be proven.

The means of the above evidence, which the judge did not fully recognize the truth. It depends on the judge's conviction in conducting an assessment of the evidence. Judge in assessing the truth of the testimony / evidence, in the RIB in the know with 3 systems of evidence include: ${ }^{4}$

1. free system (Vrij Bewijk)

2. positive system (wettellijk)

3. negative cystine (wettellijk)

Of the three systems such evidence, it turns out in the Code of Criminal Procedure we adopt a third system that is? System Negative Wettellijk "ie the judge to declare someone guilty and in law there must be confidence in the judge, and that confidence must be based on evidence legitimate. $^{5}$

One type of evidence that can assist the judge in giving legal is master testimony. In certain criminal cases such as corruption, master testimony has a major role in determining whether there is a fault errors made by a defendant. master testimony is one of the evidences an

4 M, Yahya Harahap, 2010, Discussion of Problems and Application of the Criminal Procedure Code, Sinar Grafika, Jakarta, p. 229 5 Ibid. 
important role as set out in Article 184 Criminal Procedure Code.

One important element in the crime of corruption is the element of a real loss to the state. Calculation of state losses can only be done by a master. Master here are not only master in the field of financial audit but also engineers who will calculate the feasibility of construction of a building in case of corruption was related to the construction field.

Each handling of corruption cases, the process of calculating the amount of state losses in practice are still causing differences of interpretation either by the Prosecutor, state audit agency (BPK), the financial supervision and development (BPK), as well as the court.

Based on the description above, it can be formulated an issue as follows: "How validity of master testimony construction that does not have competence in corruption cases?"

\section{B. DISCUSSION}

\section{Master Testimony as one Evidence at Trial}

Master testimony is the opinion of the person who was given under oath in the trial of the case is known in his experience and knowledge. ${ }^{6}$ The definition refers the provisions of Article 1, point 28 Criminal Procedure Code that master testimony is the testimony given by a person who has special master ise about the things necessary to make light of a criminal case for the purpose of examination ".

Seone is said to have or have specialized master ise, in this case a character still an abstract concept. Although even have an abstract concept, but in this case the statement of the master was deemed paramount in order to assist law enforcement officials, especially judges in court in order to prevent the occurrence of a judicial error, whether the error in the subject, the object and the application of the law in the process of investigation and criminal justice.

Special skills mentioned in Article 1 , point 28 of the Criminal Procedure Code, in that it can be interpreted with regard to the ability to explain or describe to a particular object in order to assist the criminal justice process. Ability here based on the experience, skills or knowledge possessed by the witness. The term "Experience ? typically attached to the empirical world and instead the term 
"experience ? usually placed in the realm of theory, but did not rule one can only be regarded as having "special skills ? because it bears the two professions at once, namely as a theoretical as well as practitioners.

Viewed from above the rules in the Criminal Code, when researched and examined where the Criminal Procedure Code does not regulate the terms specifically about what he listens to a statement of the master in the examination in court. As called for in the Criminal Procedure Code is as long as he has special master ise ? about the things necessary to make light of a criminal case and submitted by certain parties, the statement could be heard for inspection.

The presence of a master in the hearing may be requested by the defendant, as well as the Public Prosecutor. Besides hearing the presiding judge may appoint a person or persons of master to provide information either by mail or in writing, which was confirmed by oath or affirmation according to the truth of all knowledge and experience. Master testimony is required to increase the confidence of judges on an issue in a particular field, that it can only beexplained by a master in the concerned field, for example a master in the field banking, master in the field of Public Administration, ballistics master and others.

Porigin subsection 184 (1) Code of Criminal Procedure expressly directed the master testimony as a valid evidence, as in the formulation of Article 184 paragraph (1) Criminal Procedure Code, which specified that legal evidence is:

a. witness testimony;

b. master testimony;

c. letter;

d. guidance;

e. testimony of the defendant.

But, despite master testimony have had a stronger position in the Criminal Code, but in the opinion of a Judge M. Yahya Harahap is not absolutely bound to a statement of the master .? Yahya Harahap write about problems the strength of evidence from master testimony as follows: ${ }^{8}$

..., The value of the strength of evidence attached to the statement of the master evidence have proof strength values ?? free ?? or vrij bewijskracht. In him there is no inherent value of the strength of evidence was perfect and decisive.

7 M, Yahya Harahap, op.cit, p. 230

8 Ibid, p. 230 
Justice up to the judgment. Judges are independent and not tied to her vote. There is no requirement for the judge to have to accept the truth of the statements of master referred to.

\section{Remarks Validity of}

Construction Master Have No

Competence In Corruption Case

In connection with legal issues concerning the implementation of the construction of a building, the government has issued Law No. 19 of 1999 on Construction Services. Article 36 paragraph (1) of Law Number 18 of 1999 on Construction Services states:

(1) Completion of construction disputes can be reached through the courts or out of court based on voluntary choice of the parties to the dispute.

Whereas furthermore Article 37 paragraph (2) of Law Number 18 of 1999 on Construction Services affirmed:

(2) Completion of construction disputes referred to in paragraph (1) may use the services of the parties agreed upon by the parties.

The Government has issued Indonesian Government Regulation No. 29 of 2000 tImplementation Entang Construction Services, ssa implementation of Law No. 18 of 1999 on Construction Services, which in his judgment stated:

Construction services have a strategic role in national development so that its implementation needs to be regulated to achieve the binding order and organization of the construction work, construction work quality, and increasing the role of society.

In connection with the failure of the building, according to the provisionzzs of Article 36 paragraph (1) the Indonesian Government Regulation No. 29 of 2000 tImplementation Entang expressed Construction Services

(1) Chapter building was assessed and determined by 1 (one) or more master reviewers professional and competent in their field and be independent and able to provide an objective assessment, which must be established no later than 1 (one) month from the receipt of a report on the failure of the building.

Further, in the explanation of Article 36 Paragraph (1) The Indonesian Government Regulation No. 29 of 2000 tImplementation Entang Construction Services stated that:

What is meant is the master appraiser appraiser master in the 
field of construction. Appraisers master consists of individuals or groups of individuals or business entities that agreed by the parties, who are independent and able to provide an objective assessment and professional.

The provisions of Article 37 of the Indonesian Government Regulation No. 29 of 2000 tImplementation Entang Construction Services stated:

Appraisers master referred to in Article 36 paragraph (1) must have a certificate of membership and registered in the

In order to melaksanakan the provision of Article 37 paragraph (2) of Law No. 18 of 1999 on Construction Services and Article 35, Article 36, Article 37 of Government Regulation No. 29 Year 2000 on Provision of Construction Services, has issued regulation Institute of National Construction Services Development Number 42014 About valuer Master Construction Services.

Master valuer according to Article 1 point 5 National Regulation of Construction Services Development Board No. 4 of 2014 About the Master Appraisal Construction Services is a person who has competence assessment of master in the field of construction services.

According to Article 4 paragraph(1) Regulation of the National Construction Services Development Board No. 4 of 2014 About the Master Appraisal Construction Services stated:

(1) PenMaster use values play a role in the activities of master judgment on the incident Building Failure, Failure Construction Jobs, differences of opinion among the parties in the implementation of the Labor Contract Construction, construction dispute resolution and judicial processes.

Whereas furthermore according to Article 4 paragraph (2) of Regulation National Construction Services Development Board No. 4 of 2014 About the Master Appraisal Construction Services stated:

(2) Master marking can be done by 1 (one) or more Assessors Master and in accordance with Article 4 (3) Appraisal Master in carrying out its duties may be assisted by master, and / or other support.

(3) Master reviewers in the execution of their duties can be assisted by master. This is confirmed in Article 4, paragraph 
(3) of the Regulation of the National Construction Services Development Board No. 4 of 2014 About the Master Appraisal Construction Services Sector which states:

(4) Master use values in performing their duties may be assisted by master, and / or other support.

That deals with the task of the master appraiser, provided by Article 5 National Regulation of Construction Services Development Board No. 4 of 2014 About the Master Appraisal Construction Services Sector which states:

(1) Appraisal Master in building failure events is to provide an assessment and determination:

a. Because failure the building;

b. parts that are no longer functioning due to the failure of Buildings;

c. party has responsible for the failure of building going on, and the degree and nature of the mistakes made;

d. Apaint a mixed picture loss, and the proposed amount of compensation to be paid by the party or parties who make mistakes; and

e. payment term losses.
(2) Appraisal Master in terms of the incidence of failure of Construction Works is to provide an assessment and recommendation:

a. because the failure of Construction Works;

b. parts that are no longer functioning due to the failure of Construction Works;

c. party responsible for the failure of construction work going on, and the degree and nature of the mistakes made; and

d. Apaint a mixed picture of losses, as well as suggested ways of failure repair construction work

(3) Appraisal Master in terms of the incidence of differences of opinion between the parties, is:

a. contractual interpretation offered are as skilled on Construction Work Contract documents;

b. offered are the opinion and / or research paper on the problem of differences of opinion to reach an agreement;

c. completion of the proposals offered are to reach an agreement; and / or 
d. formulate the agreement of the parties.

(4) Appraisal Master in terms of the incidence of dispute settlement construction is as Mediator or conciliator.

(5) Appraisal Master as Mediator referred to in paragraph (4) includes:

a. memfacilitation of the parties in the settlement of disputes;

b. secondaryi any dissent in the argument;

c. membecontractual interpretation offered are as skilled on the document Employment Contract Construksi; and

d. membeoffered are the opinion and / or research paper on dispute settlement issues to reach an agreement;

(6) Appraisal Master as a conciliator, as referred to in paragraph (4) includes:

a. facilitation of the parties in the settlement of disputes;

b. secondary any dissent in the argument;

c. contractual interpretation offered are as skilled on Construction Work Contract documents; d. offered are the opinion and / or research paper on dispute settlement issues to reach an agreement;

e. completion of the proposals offered are to reach an agreement; and

f. formulate the agreement of the parties.

(7) Appraisal Master in the arbitration process and the judicial process is to provide master testimony as a master witness.

Under the provisions of the above it can be seen duty master appraiser, yanag one of them according to the provisions of Article 5 (7) is to provide master testimony as a master in the judicial process. This suggests that in the field of construction services, master who can testify in court only Appraisal Master

As stated in Article 5 (7) of the Regulation of the National Construction Services Development Board No. 4 of 2014 About the Master Appraisal Construction Services, Master Appraisal only to testify as a master in court. That could be the alpha Master Appraisal there are criteria to be met for the Appraisal Master , as provided for in Article 8 of the Regulation of the National Construction Services 
Development Board No. 4 of 2014 About Appraisal Master Construction, affirms:

Master use values shall meet the following criteria:

a. have experience in a construction work of at least 10 (ten) years;

b. have SKA in the field of Construction Services with subqualifiers at least associate master

c. have i SPA;

d. can work in an honest, objective and independent;

e. can implement the code of Conduct and the Code Master Appraisal Master Appraisal; and

f. registered in the National LPJK;

According to Article 1 point 13 National Regulation of Construction Services Development Board No. 4 of 2014 About the Master Appraisal Construction Services, Certificate of Master ise, hereinafter referred to as SKA is:

certifikat published LPJK and given to the construction master who have met requirements based on the scientific disciplines, kefungsian and / or particular master ise.

According to Article 1 point 14 National Regulation of Construction
Services Development Board No. 4 of 2014 About the Master Appraisal Construction Services, Master Appraisal Certificate, hereinafter referred to as the SPA are:

Certificate published by LPJK of National and given to master who have met the requirements as Appraisal Master .

Master valuer must be registered with the National Construction Services Development Board (LPJKN). Master registered valuer will get the registration of the National Construction Services Development Board (LPJKN). In that Article 1 number 15 National regulation of Construction Services Development Board No. 4 of 2014 About the Master Appraisal Construction Services stated:

Registration Appraisal Master is the activity took note of Master Appraisal competence in accordance with the results of Master Appraisal competency assessment.

Like as the provisions of Article 9 paragraph (1) of Regulation National Construction Services Development Board No. 4 of 2014 About the Master Appraisal Construction Services stated: Master use values must comply with the provisions of competence 
in accordance with competency standards set by the Master Appraisal National LPJK

Furthermore that according to Article 9 paragraph (2) of Regulation National Construction Services Development Board No. 4 of 2014 About the Master Appraisal Construction Services mentioned

Standar competence as referred to in paragraph (1) shall include:

a. Competency to conduct a master assessment of the incidence of failure of Construction Works;

b. Competency to conduct a master assessment of the incidence of failure of buildings;

c. Competency to conduct a master assessment of the incidence of dispute settlement construction and different opinions among the parties

d. Competency as a master witness in the arbitration hearing or trial

Master use values must comply with the provisions of competence in accordance with competency standards set by the Master Appraisal National LPJK, sosomeone who does not have the competence as a master appraiser is not justified to activities under the authority of an Appraisal Master .
Someone to do the task as a master appraiser, one must have competence as evidenced by the master reviewers Master Appraisal Certificates, so anyone who does not have the Master Appraisal Sertpikat not justified and prohibited from doing duty as a master Appraisal.

If there are people who are not as Appraisal Master examination and calculation of the quantity and the price of a building, then the calculation results of the examination or someone who is not as Appraisal Master is invalid.

In case he is not a master appraiser, then the results of the examination or calculation set out in a report can not be regarded as the result of the master appraisal report, so and thus the results of the report is invalid because it was made by a person who is not authorized or incompetent.

Only the results of Master Appraisal report alone can be used as evidence in court because only Appraisal Master who can be questioned as a master in the field of construction in the trial, apart from it can not.

Someone who does not have a Certificate of Appraisal Master could 
not testify in court because it does not qualify as a formal Appraisal Master . It can be seen in the provisions of Article 5 (7) in conjunction with Article 9 paragraph (2) National Regulation of Construction Services Development Board No. 4 of 2014 About the Master Appraisal Construction Services, namely competence as a master witness in the arbitration hearing or trial.

Related to the Master Appraisal task execution, in the line of duty, Master Appraisal usually form a team according to the needs and tasks assigned and Appraisal Master is responsible for the work of the team formed by the Master Appraisal.

Associated with a master who has the competence docalculating the quantity of a building and the price of a building is a person who has a construction management certification. $\mathrm{He}$ has the competence do work related to construction management so as to determine the value of a building to use the services of a master who has a certificate as majanamen construction.

Against the strength of a building, which has the competence to perform testing is someone who has master ise in the field of building construction which is proven by the certification of master ise in the field of building. Therefore we tested is a construction of a building, it is entitled and authorized to conduct testing is someone who has master ise in the field of building construction as evidenced by a certificate of master ise in the field of building construction not a master on roads and bridges.

In terms of assessing a construction, therefore has the right and authority to conduct testing is someone who has master ise in the field of building construction, the results of tests performed by someone whose background outside masons eg master roads and bridges can not be accounted for and is not valid.

\section{CONCLUSION}

Based on the discussion in advance of exposure, it can be concluded that the master who has the competence do calculating the quantity of a building and the price of a building is a person who has a construction management certification. Description Construction Master who have no competence in the matter of corruption, the statement becomes invalid. 



\section{BIBLIOGRAPHY}

\section{Books:}

Chazawi Adami, 2006, the Law of Evidence and Act. Of Corruption, PT Alumni, Bandung

Hamzah Andi, 2010, the Criminal Procedure Code, Sinar Grafika, Jakarta, in 2010.

Harahap Yahya M., 2005, the Criminal Procedure Code Discussion of Issues and Implementation Hearings, Appeals, and Review, Sinar Grafika, Jakarta.

Laksana, Andri Winjaya. "AKIBAT MINUMAN KERAS DI KOTA SEMARANG (Studi Kasus Di Polwiltabes Semarang)." Jurnal Pembaharuan Hukum I, no. 3 (2014): 297-306.

Mertokusumo, Sudikno 2008, the Civil Procedure Code Indonesia, liberty, Yogyakarta,

MuhAmmad Rusli, 2007, Code of Criminal Procedure Contemporary, PT Citra Aditya Bakti, Bandung.

Yourlyadi Lilik, 2007, Ruling Justice in Criminal Proceedings, PT Citra Aditya Bakti, Bandung.

Purnomo, Bambang 2005, the Criminal Procedure Law Principles of Indonesian Criminal Justice, Liberty, Yogyakarta

Pangaribuan Luhut MP, 2013, the Criminal Procedure Law. Official Letter Advocate in Court, Papas Sinar Sinanti, Jakarta

Sasangka Day and Rosita Lily, 2003, LawProof In Criminal Cases, Mandar Maju, Bandung.

\section{Legislation:}


The Act. No. 19 of 1999 on Construction Services

Indonesian Government Regulation No. 29 of 2000 on Implementation Entang Construction Services

National Regulation of Construction Services Development Board No. 4 of 2014 About the Master Appraisal Construction Services A 